\title{
PERFORMANCE PROPERTIES OF TERRY FABRICS FOR HOTEL TOWELS
}

\author{
Svitlana Arabuli ${ }^{*}$, Arsenii Arabuli ${ }^{1}$, Olena Kyzymchuk ${ }^{1}$
}

1 (Kyiv National University of Technologies and Design, Ukraine *e-mail: arabuli.si@knutd.edu.ua)
Scientific paper

UDC: 677-037: 678.2:687.2

doi: $10.5937 /$ tekstind2104054A

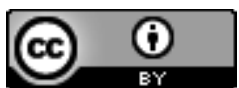

Abstract: The state and standards of provision of hotels in Ukraine with terry towels are presented in this paper. The range of hotel terry towels is analyzed. The main factors that affected the modern assortment of textile materials for hotel terry towels are considered. The main focus is on the classic range of terry fabrics with double piles for hotel towels. The analysis of physical, mechanical and optical properties of terry fabrics for hotel towels is given. Indicators that characterize the interaction of fabric with drip-liquid moisture have been experimentally determined. The paper presents the results of the investigation of terry fabrics ' performance after 1,5 and 10 washing cycles. The terry fabric with $500 \mathrm{~g}$ per sq. $\mathrm{m}$ density and with a twisted loop $3.5 \mathrm{~mm}$ high provides the best performance and is recommended for use in hotel towel manufacturing.

Keywords: terry fabric, mechanical properties, physical properties, optical properties, cotton, hotel.

\section{PERFORMANSE SVOJSTVA FROTIRNIH TKANINA ZA HOTELSKE PEŠKIRE}

Apstrakt: $U$ ovom radu su predstavljeni stanje i standardi snabdevanja hotela u Ukrajini frotirnim peškirima. Analiziran je asortiman hotelskih frotirnih peškira. Razmatraju se glavni faktori koji su uticali na savremeni asortiman tekstilnih materijala za hotelske frotirne peškire. Glavni fokus je na klasičnom asortimanu frotirnih tkanina sa duplim frotirnim gomilama za hotelske peškire. Data je analiza fizičkih, mehaničkih i optičkih osobina frotirnih tkanina za hotelske peškire. Eksperimentalno su određeni indikatori koji karakterišu interakciju tkanine sa tečnom vlagom. U radu su prikazani rezultati ispitivanja performansi frotirnih tkanina nakon 1, 5 i 10 ciklusa pranja. Frotir sa gustinom od $500 \mathrm{~g}$ po $\mathrm{m} 2$ i sa upletenom petljom visine 3,5 mm pruža najbolje performanse i preporučuje se za upotrebu u proizvodnji hotelskih peškira.

Ključne reči: frotir, mehanička svojstva, fizička svojstva, optička svojstva, pamuk, hotel.

\section{INTRODUCTION}

Hotels are a major component of the industry of hospitality. Today, the creation of a quality service system that allows the provision of competitive hotel services is one of the major tasks and problems of Ukrainian hotel complexes. Quality is an important tool in the fight for hotel services markets. Only high-quality services open the road to solvent western markets [1], [2]. Some countries have adopted a single classification system of hotels, which regulates their standards
[3]. In addition, there are national classification systems of hotels in almost every country, which have their own unique features. This issue is under government control in some European countries that have not approved Hotelstars Union.

The supply chain of the hotel as well as its household part are important components of the hotel services. The hotel is equipped with towels and bedding, linens and tablecloth. Their quality and condition determine the living comfort and hospitality largely. There are a few different types and towel sizes. They 
include: face towel (washcloth), hand towel, bath mat, bath towel, bath sheet and bathrobes. The standard measurements for hotel terry towels are the following: $30 \times 30 \mathrm{~cm}$-face towel; $50 \times 70 \mathrm{~cm}$ - hand towel (also $50 \times 100 \mathrm{~cm}$ ) and bath mat; $70 \times 140 \mathrm{~cm}$ or $70 \times 150$ $\mathrm{cm}$-bath towel; $100 \times 200 \mathrm{~cm}$-terry blanket or bath sheet. The World Tourism Organization, which determines the parameters of "stardom", does not set clear requirements to the number of terry towels in the hotel room [3]. In a luxury hotel, there are usually four towels for every guests.

Taking into account the purpose and category of the hotel, the standards set for the change of linen and towels, the conditions of its washing and storage. In the world practice of hotel business, the norms of linen and towels replacement once in 3 days are considered typical. They meet hygienic norms. In high-class hotels, linen and towels are replaced daily [4], [5]. The system for determining the quality level of hotel services in Ukraine is based on the standard DSTU 4269: 2003 [6]. This standard sets general requirements for the hotels of different categories, among which the norms of towels quantity and their replacement frequency in different categories hotels (see Table 1).

Thus, according to the state standard of Ukraine towels must be replaced daily in three-star hotels. But frequent washing is harmful to towels, so it is rational to replace them as they are used, taking into account the guest's desire, but at least according to hygienic standards. Therefore, an appeal to the guests, in which they are asked to throw towels, unfit for further use, on the floor, which is a sign to replace them, are placed in the bathrooms of some hotels. It also meets the requirements of the greening hotel business.

Terry towels are also available in various densities that is measured in grams of fabric per square me- ter. The most common density for hotel terry towels is $400-600 \mathrm{~g}$ per sq.m. Luxury hotels use terry towels with a density up to $800 \mathrm{~g}$ per sq.m and this is the maximum density used. The most standard hotel terry towel has the $400-500 \mathrm{~g}$ per sq.m density and it is optimal in terms of all aspects (absorbency, softness, price, price of washing, etc.)

Terry towels are available in a multitude of colours and designs. Hotels generally use white terry towels because of their easy use. it is much more efficient to maintain one-colored textiles in a hotel's laundry. From the other point, if the towels are washed at 60 degrees, the colour of the terry towel will fade in time. The purpose of a hotel is to use a terry towel for as long as possible. If it is washed 100-300 times within a couple of years, its appearance and shape may change to a large extent. It is important to consider shrinkage in the washing. Terry towels shrink down $1-2 \%$ from the original width and $5-10 \%$ from length The evaluation of the performance properties of hotel terry towels available on the Ukrainian market is the purpose of this research.

\section{EXPERIMENTAL}

Hotel towels are a rectangular product made of terry fabric, used to wipe the wet face, hands, feet, or body as a whole.

Terry fabric is a fabric whose surface consists of piles in the form of loops of the main threads, which are earned between the root threads of the warp and weft [7]. Pile plays major role for a towel for its water absorbency and other properties [8]. The pile can be either single (Fig. 1. a) or double (Fig. 1.b). In addition, terry fabric can be manufactured with a relief pattern and with a clipped pile.

Table 1: Requirements to terry towels in a hotel room in Ukraine [6]

\begin{tabular}{|c|c|c|c|c|c|c|}
\hline \multirow{2}{*}{ № } & \multirow{2}{*}{ Requirement } & \multicolumn{5}{|c|}{ Hotel rank (stars) } \\
\hline & & * & $* *$ & $* * *$ & $* * * *$ & $* * * * *$ \\
\hline \multicolumn{7}{|c|}{ Sanitary equipment of the room } \\
\hline 1 & $\begin{array}{l}\text { Inventory and items of sanitary and hygienic } \\
\text { equipment of the bathroom }\end{array}$ & & & & & \\
\hline 1.1 & towels for each guest, not less than & 2 & 2 & 3 & 4 & 4 \\
\hline 1.2 & in particular a bath towel & + & + & + & + & + \\
\hline 1.3 & bathrobe (for each guest); & & & & & + \\
\hline 1.4 & bath cap (for each guest) & & & + & + & + \\
\hline 1.5 & bath slippers (for each guest) & & & & & + \\
\hline \multicolumn{7}{|c|}{ Services } \\
\hline 2 & Towels replacement & & & & & \\
\hline 2.1 & every three days or at the guest request & + & + & & & \\
\hline 2.2 & every day or at the guest request & & & + & + & + \\
\hline
\end{tabular}




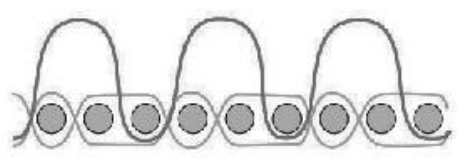

a

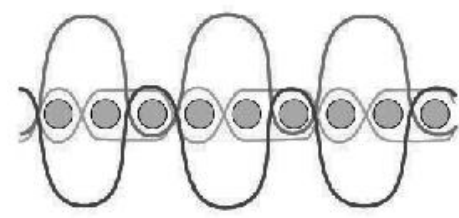

b

Figure 1: Cross-section of terry fabric:

a - with single pile (loops on one side);

b - with double pile (loops on both sides)

According to DSTU GOST 11027-2014 and DSTU EN 14697: 2018 [9], [10] the normalized indicators of the quality of terry fabrics are following:

- Type and mass of cotton fiber - $100 \%$;

- Breaking load: on the warp - not less than $176 \mathrm{~N}$; on a weft - not less than $235 \mathrm{~N}$;

- Water absorption - not less than $300 \%$;

- Capillary - not less than $100 \mathrm{~mm}$.

The breaking load characterizes the semi-cycle tensile characteristics and is used to evaluate the ultimate mechanical properties of textile fabrics. This indicator is of great importance in predicting the wear resistance of the material, as well as its durability.

The performance of terry fabric is mainly assessed by its absorbency that refers to both the rate at which the fabric absorbs the water i.e. dynamic water absorbency; and the total water retention ability of the fabric i.e. static water absorption. Hight loop shape factor is the key to improve the absorbency behavior of the terry fabric [11]. It was seen that the increase in pile height causes an increase in fabrics' velocity of water absorption value in the weft direction [12]. From another study it was found that surface water absorbency is not related to the material composition, but the drying time is closely connected with the given composition [13].

Given the using intensity of hotel terry towels (table 1), an important characteristic of the materials is durability and resistance. The performance change, as shown in previous studies [11], [14], is the result of the simultaneous and periodic influence of many factors. The impact depends on the using conditions of the towels, the type of raw material, and the fabric texture. Gradually changes by a complex of factors occur in the micro- and macrostructure of terry fabric. They lead to a deterioration of the fabric's properties and appearance. This process ends with towel destruction.

Hotel terry towels are in direct contact with the human body and moisture, which is removed from the surface of the human body, absorbing it by towel structure, and are exposed to constant "washing ". Towels lose their marketable appearance and become unusable for further use. The complex of physicochemical and mechanical factors affects terry towel appearance during repeated "washing". Type of detergent, temperature and humidity, ironing temperature are physicochemical factors; pressure during ironing and wet abrasion of the surfaces between the fabric and parts of the washing machine, multiple tensile deformation, bending, compression, and torsion are the mechanical ones.

The topography of towel destruction depends on the purpose of the product (for feet; bath for the body; for the face; for hands), the using conditions and individual characteristics of human behavior and habits. First of all, the areas in the middle of the towels are destroyed, which are exposed to the intense influence of a complex of destructive factors. These areas determine the operation time of the product, its suitability or unsuitability for further use. The use of terry fabrics is accompanied by a decrease in their weight, the loops destruction, reducing the strength of the ground loops and their cutting, the structure loosening and as a consequence - the complete destruction of the material.

Therefore, it would be expedient to study the performance of terry fabrics after repeated washing.

\subsection{Materials and Preparation}

5 terry fabrics with double piles of the same interweaving available on the textile market of Ukraine were studied in this research. Country of origin is Turkey. A drawing of the interweaving and cross-section of the studied terry fabrics is shown in figure 2 . The interweaving repeat: on the warp is 4 threads, on the weft is 3 threads. The first and third threads of the warp are ground that form the fabric basis; the second and fourth threads are piles that form loops on both sides of the fabric. 


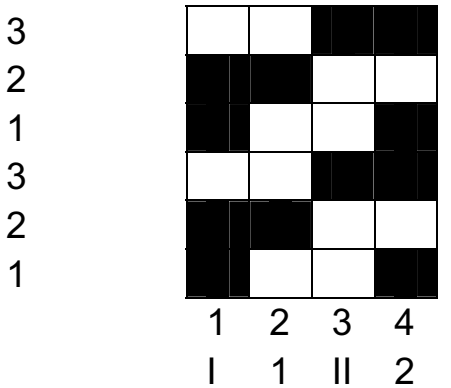

a

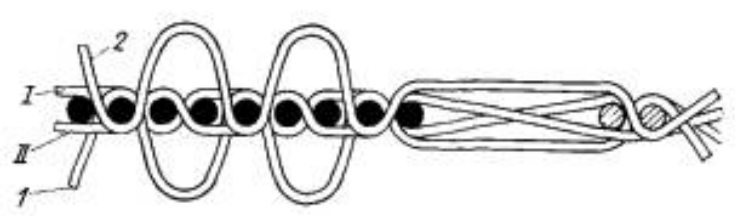

b

Figure 2: Terry fabric. $a$ - interweaving pattern; $b$ - cross section

The fabric structure and normalized indicators for towels were studied by standard methods. In this study, the normalized indicators were supplemented by the bending stiffness and color characteristics, which are important properties in assessing the tactile and optical performance of terry towels.

Bending stiffness allows to indirectly assess the consumer feels when touching the skin and absorbing moisture from the human body. It is characterized by softness, pleasantness to the touch. It is known that the natural stiffness of the fibers, the structure of yarn and threads, the fabric's thickness, surface density, interweaving and finishing affect the ability of a material to resist shape change during external bending force. The measurements of the bending stiffness of textiles were carried out on PT-2 according GOST 10550-93 Textiles. Cloth. Methods for Determination of Resistance to Bending.

The measurement of the reflection spectra and the calculation of the color characteristics of the fabrics were carried out on the Colorimeter 3NH NR20XE. The paper presents the characteristics with radiation D-65/10, color differences were calculated in the system CMC (1: 1) and CIE LAB (fig.3). The following indicators were used for the differentiated analysis of optical properties of terry fabrics [15]:

Chroma:

$$
C^{*}=\left[\left(a^{*}\right)^{2}+\left(b^{*}\right)^{2}\right]^{1 / 2}
$$

Hue angle:

$$
h^{*}=\operatorname{arctg}\left(a^{*} / b^{*}\right)
$$

Lightness:

$$
L^{*}=25\left[100\left(y / y_{0}\right)^{1 / 2}\right]-16
$$

where $a^{*} i b^{*}$ - color coordinates: $a^{*}$ - red/green value; $b^{*}$ - blue/yellow value.

The effect of 1, 5, and 10 washing cycles on the performance of terry fabrics was investigated in this

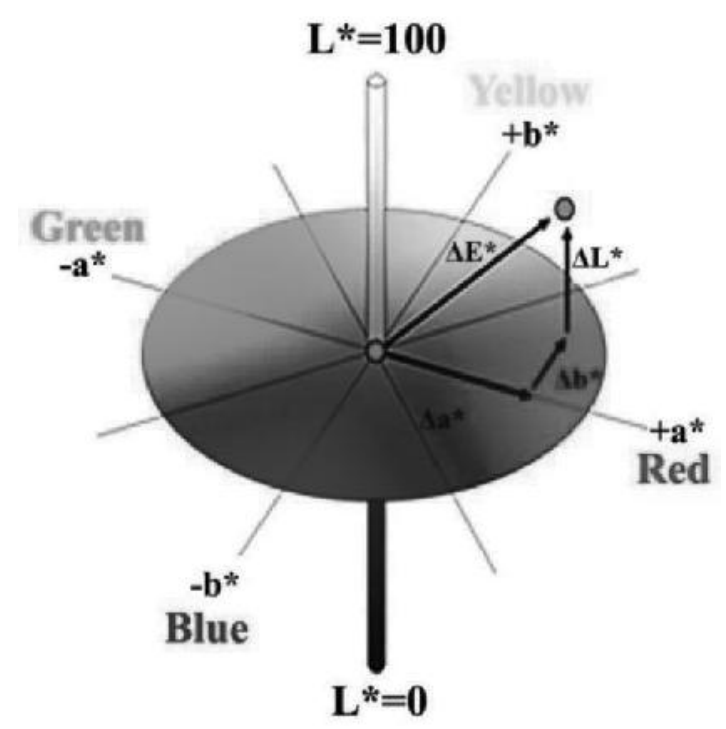

Figure 3: Three-dimensional system CIE LAB

research. Washing of fabrics`samples was performed in an automatic washing machine according to the C4П4O8B1P1 mode, described in detail in [16]. The studies of the resistance of terry fabrics to the wet treatments were performed on the following indicators: breaking load and elongation; bending stiffness; water absorption and capillarity; colorimetric indicators.

\subsection{Structural characteristics}

Results of the study of the structural characteristics of terry fabrics are shown in Table 2. It is clear that fabrics are differed by pile wrap and loop heigh. An increase in loop height leads to an increase in fabric's thickness and mass pes square meter respectively. Fabric \#1 has got the lowest density and fabric \#5 has got the highest one. 
Table 2: Structural characteristic of terry fabrics for towels

\begin{tabular}{|c|c|c|c|c|c|c|}
\hline$\#$ & Consumtion & Fabric structure & $\begin{array}{c}\text { Fabric density, } \\
{[\mathrm{g./sq} . \mathrm{m}]}\end{array}$ & $\begin{array}{c}\text { Thickness, } \\
{[\mathrm{mm}]}\end{array}$ & Pile wrap & $\begin{array}{c}\text { Loop type and } \\
\text { height, [mm] }\end{array}$ \\
\hline 1 & $100 \%$ Cotton & Terry with double pile & 400 & 1.6 & $16 / 1$ & twisted 3.0 \\
\hline 2 & $100 \%$ Cotton & Terry with double pile & 500 & 2.1 & $20 / 2$ & twisted 3.5 \\
\hline 3 & $100 \%$ Cotton & Terry with double pile & 550 & 2.5 & $20 / 2$ & twisted 3.5 \\
\hline 4 & $100 \%$ Cotton & Terry with double pile & 600 & 2.9 & $20 / 2$ & twisted 3.5 \\
\hline 5 & $100 \%$ Cotton & Terry with double pile & 800 & 3.1 & $20 / 2$ & twisted 5.0 \\
\hline
\end{tabular}

\subsection{Mechanical properties}

Results of the study of the mechanical properties of terry fabrics are shown in Table 3.

Results of the tensile load investigation showed that fabrics \#2 and \#4 have got the biggest strength. In the "warp" direction a breaking load value for all fabrics is within the normalized, namely, more than $176 \mathrm{~N}$. In the "weft" direction a breaking load values for the fabrics \#1 $\left(P_{b}=221 N\right), \# 3\left(P_{b}=191 N\right)$ and
$\# 5\left(P_{b}=216 N\right)$ are less than the normalized value of $235 \mathrm{~N}$. Breaking elongation is not a normalized indicator. Its values are $44 \div 52 \%$ for warp direction and $47 \div 57 \%$ for weft direction. No regularity was found between the tensile properties (table 3 ) and structural characteristics of the fabrics (table 2).

The changes in breaking load and elongation after 1, 5, and 10 cycles of washing are shown in Fig.5 and Fig.6.

Table 3: Mechanical properties of terry fabrics after first washing

\begin{tabular}{|c|c|c|c|c|c|c|c|}
\hline \multirow{2}{*}{$\#$} & \multirow{2}{*}{$\begin{array}{c}\text { Fabric density, } \\
\text { [g./sq.m] }\end{array}$} & \multicolumn{2}{|c|}{$\begin{array}{c}\text { Braking load, } \\
\mathrm{P}_{\mathrm{b}}[\mathrm{N}]\end{array}$} & \multicolumn{2}{c|}{ Braking elongation, $\varepsilon$ [\%] } & \multicolumn{2}{c|}{$\begin{array}{c}\text { Bending stiffness, } \\
E I \text { [mkN*sq.sm] }\end{array}$} \\
\cline { 3 - 8 } & warp & weft & warp & weft & warp & weft \\
\hline 1 & 400 & 186 & 221 & 44 & 57 & 13666 & 8720 \\
\hline 2 & 500 & 211 & 240 & 49 & 47 & 25317 & 14217 \\
\hline 3 & 550 & 182 & 191 & 44 & 53 & 29491 & 20201 \\
\hline 4 & 600 & 176 & 240 & 48 & 48 & 33637 & 27965 \\
\hline 5 & 800 & 201 & 216 & 52 & 57 & 54566 & 46943 \\
\hline
\end{tabular}
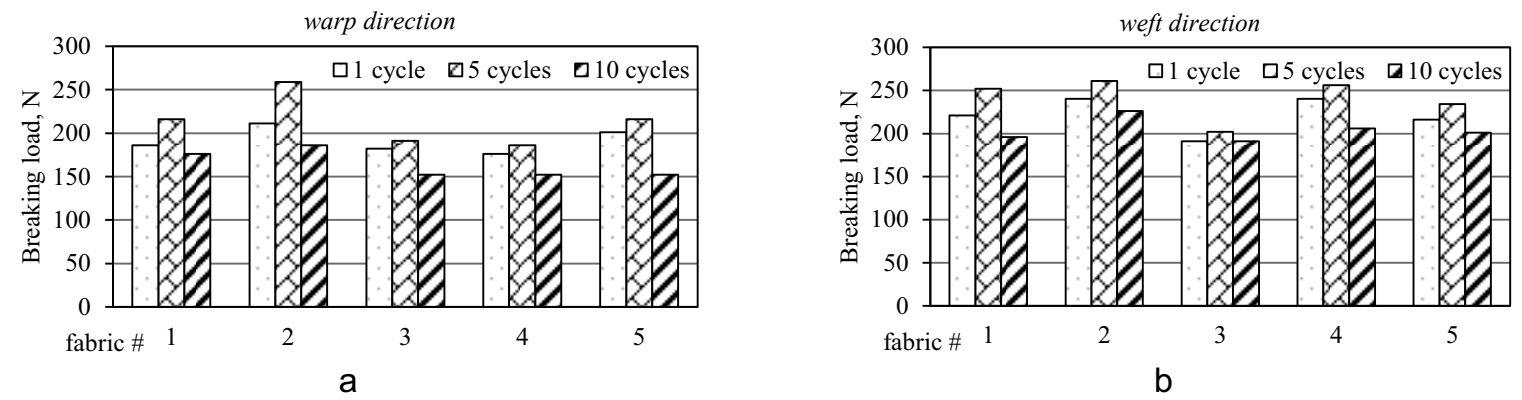

Figure 4: Changes in breaking load after washing cycles: $a$ - in warp direction; $b$ - in weft direction
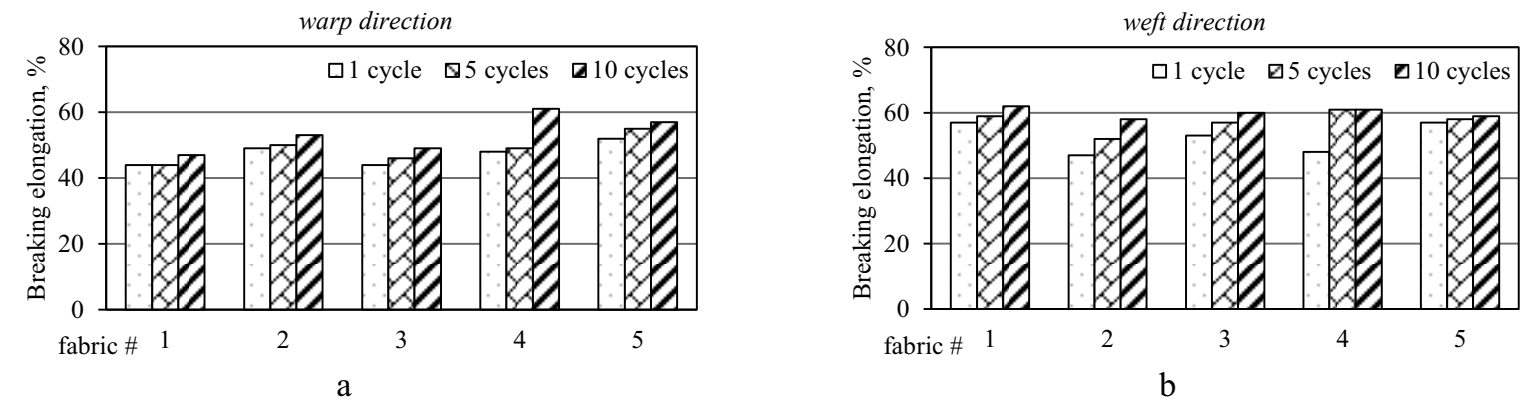

Figure 5: Changes in breaking elongation after washing cycles: $a$ - in warp direction; $b$ - in weft direction 
The research results indicate the increase in the values of both breaking load (fig.4) and breaking elongation (fig.5) in both the longitudinal and transverse directions during the first 5 cycles of "washing". It is due to the redistribution of stresses in the threads, some adjustment between warp and weft yarns, and the structures" stabilization. After 10 cycles of "washing" the breaking load decreases and becomes less than the initial value in both the longitudinal and transverse directions (Fig. 4). This is due to destruction in the fibers, threads, and fabric structure. Destruction of molecular and supramolecular structures of fibers is observed under the influence of a complex of physico-chemical factors, amplified by repeated deformations in wet conditions. Under the temperature and moisture, the fibers are in a highly elastic state, which accelerates oxidative reactions, hydrolysis of molecules, and the micro defects' development. Under the influence of repeated deformations and washing the friction between fibers and threads weaken, which leads to a loosening and gradual destruction of the fabric's structure and results in its instability. Such changes lead to a deterioration in the strength char- acteristics of terry fabrics but cause an increase in the breaking elongation (Fig. 5), which is observed for all studied fabrics in both directions.

The studied terry fabrics differ in bending stiffness significantly (table 3), established by the console's method when the specimen bends under its own weight. Fabric \#1 has got the smallest El values both in the longitudinal and transverse directions. Fabric \#5 is characterized by the greatest El values. The general trend of the study is: bending stiffness values in the longitudinal (warp) direction exceed by $15-60 \%$ the values in the transverse (weft) direction (table 5). The difference value decreases with the fabric's density increase. The direct correlation dependences between the fabrics' stiffness and gram per square meter were established (Fig. 6).

Changes in bending stiffness (EI) of fabrics after washing cycling (Fig. 7) in both the longitudinal and transverse directions are similar to changes in breaking load. Namely: bending stiffness increases after 5 cycles due to shrinkage and stabilization of the structure of terry fabrics and decreases after 10 cycles due to the stability loss and increased structure mobility.

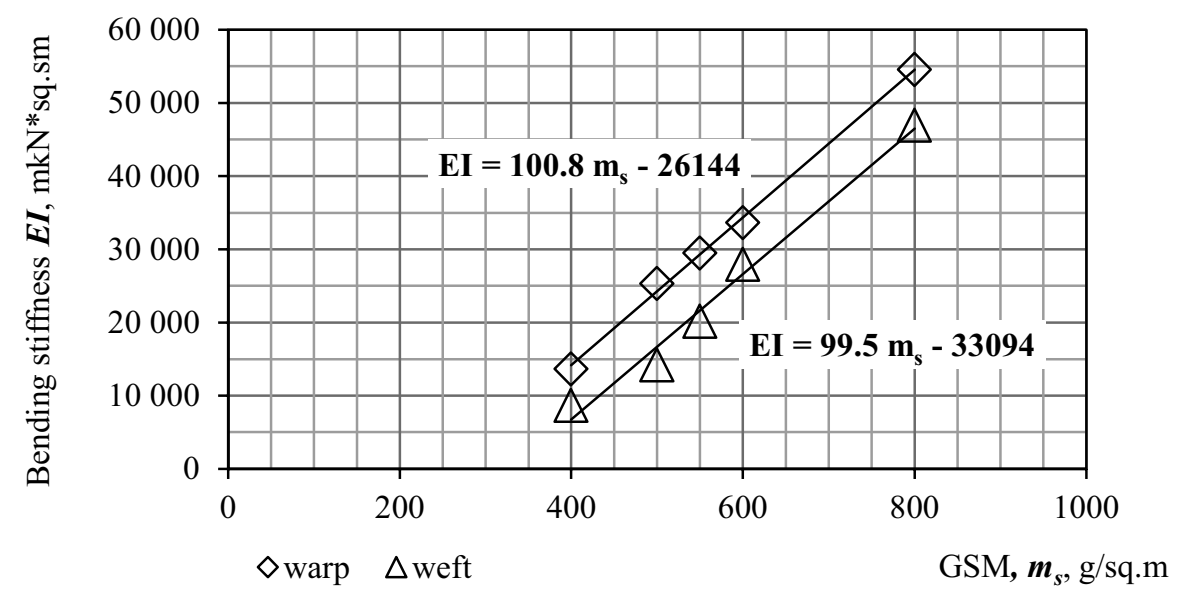

Figure 6: Dependence of bending stiffness of terry fabrics on their density
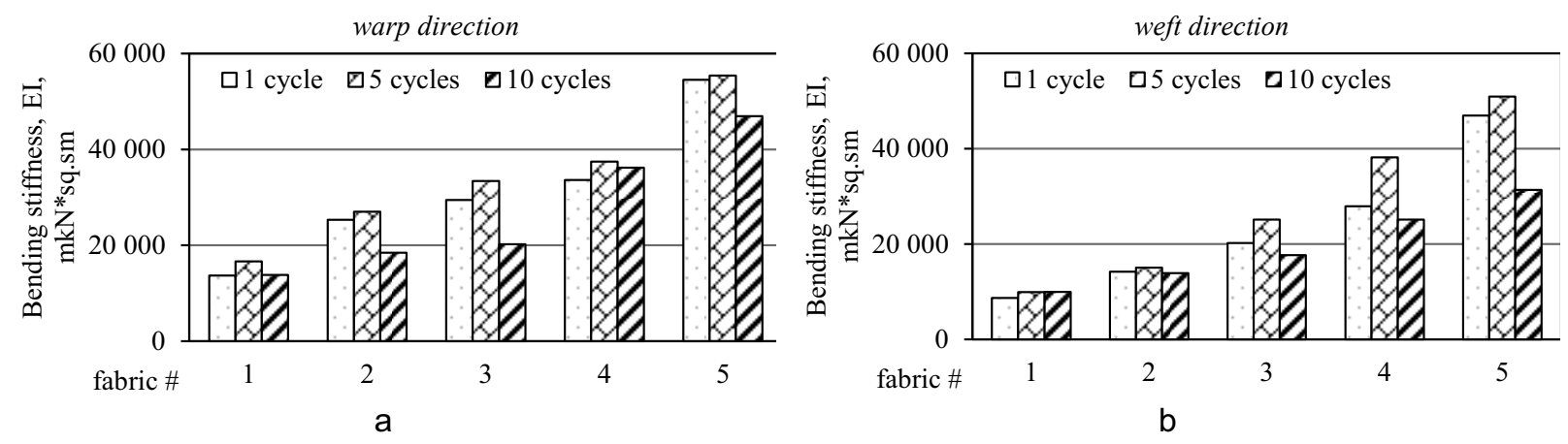

Figure 7: Changes in bending stiffness after washing cycles:

$a$ - in warp direction; $b$ - in weft direction 


\subsection{Physical properties}

Results of the study of the physical properties of terry fabrics are shown in Table 4. According to the experimental data, water-absorbing properties of studied terry fabrics meet the normalized requirement: water absorption is more than $300 \%$; capillarity is more than $100 \mathrm{~mm}$. It should be noted, all fabrics have similar water-absorbing properties, and their values do not correlate with the structural characteristics of terry fabrics. Fabrics \#2 and \# 4 have the best water absorption value (324 \%). Fabric \#2 with $500 \mathrm{~g}$ per sq.m density and with twisted loop $3.5 \mathrm{~mm}$ high has the best capillarity ( $30 \mathrm{~min}$ ) values: $140 \mathrm{~mm}$ in warp and $155 \mathrm{~mm}$ in weft directions.
Repeated washing affects not only the mechanical properties but also the physical properties of terry fabrics. Fabrics' capillarity (Fig. 8) after 5 cycles decreases in both the longitudinal and transverse directions due to shrinkage and structure stabilization: interfilamentous and interfiber pores are reduced and block fluid lifting through vertical capillaries of terry cloth. The capillarity of terry fabrics after 10 cycles increases again and reaches the initial values after 1 cycle.

There is a rapid decrease in water absorption values after repeated washing cycles (Fig. 9). It is due to changes in the fabric's structure, namely, the destruction by reducing the frictional bonds between the fibers and threads. The structure becomes more mobile and unstable.

Table 4: Physical properties of terry fabrics after first washing

\begin{tabular}{|c|c|c|c|c|}
\hline \multirow{2}{*}{$\#$} & \multirow{2}{*}{ Fabric density, [g./sq.m] } & \multicolumn{2}{|c|}{ Capillarity (30 min), K [mm] } & \multirow{2}{*}{$\begin{array}{c}\text { Water absorption, } \\
\text { W [\%] }\end{array}$} \\
\cline { 3 - 4 } & 400 & warp & weft & 303 \\
\hline 1 & 500 & 130 & 150 & 324 \\
\hline 3 & 550 & 140 & 155 & 312 \\
\hline 4 & 600 & 139 & 140 & 324 \\
\hline 5 & 800 & 120 & 115 & 305 \\
\hline
\end{tabular}
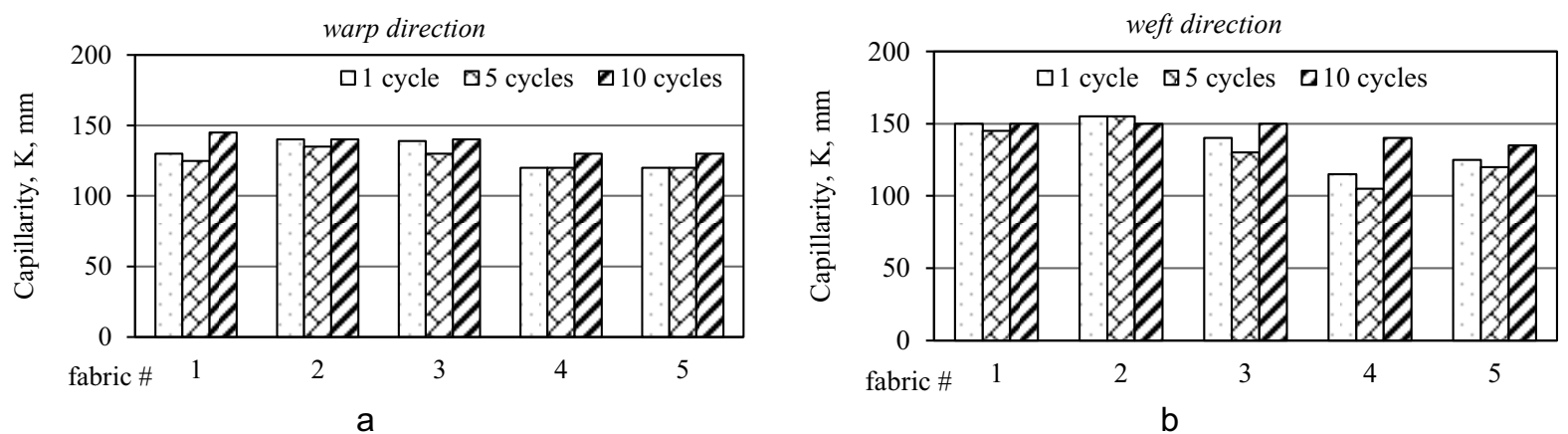

Figure 8: Changes in capillarity (30 min) after washing cycles: $a$ - in warp direction; $b$ - in weft direction

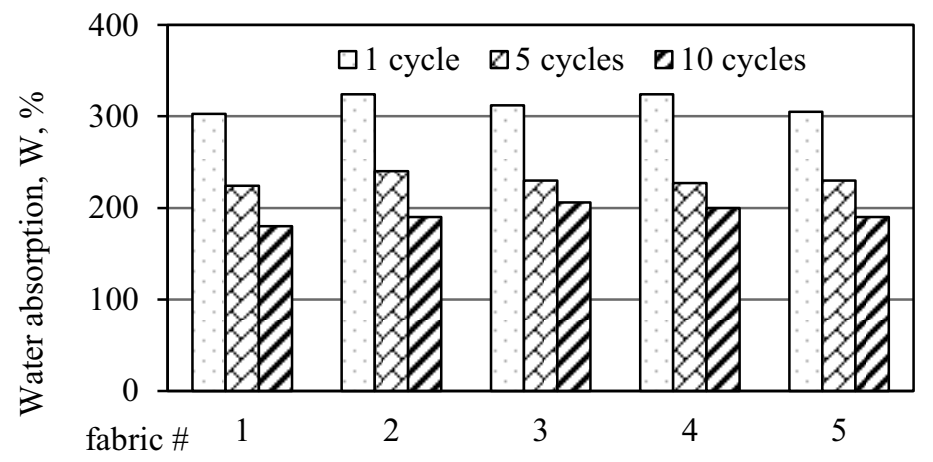

Figure 9: Changes in water absorption after washing cycles 


\subsection{Optical properties}

Results of the study of the optical properties of terry fabrics at initial state are shown in Table 5. All investigated terry fabrics are white. They have similar lightness: $L^{*}$ values are between 91.6 and 94.0 , which is close to 100 . Fabrics are differed by chroma: $C^{*}$ values are from 0,68 (\#2) and 0.69 (\#5) to 1.87 (\#4). Hue angles are similar ( $h^{*}=84 \div 97$ ) for almost all fabrics except fabric \#2 $\left(h^{*}=69.49\right)$
As can be seen, the color difference after wet treatments fabric \#2 is "invisible" $\Delta \mathrm{E}=0.0$ to 1.0 even after 10 washing cycles. the color differences for the rest fabrics became "visible" $\Delta \mathrm{E}=2.0$ to 4.0 after 5 washing cycles. That is, the human eye feels the difference in the color of terry fabrics №1, 3, 4, 5 after 5 and more washing cycles. It should be noted that color differences values are greater for fabrics \#4 and \#5.

Dependences of lightness $\left(L^{*}\right)$ and chroma $\left(c^{*}\right)$ on washing cycles are shown in fig.10 and fig. 11.

Table 5: Optical properties of terry fabrics in initial state

\begin{tabular}{|l|c|c|c|c|c|}
\hline \multirow{2}{*}{\multicolumn{1}{c|}{ Indicator }} & \multicolumn{5}{c|}{ Fabric \# } \\
\cline { 2 - 6 } & 1 & 2 & 3 & 4 & 5 \\
\hline Lightness, $\mathrm{L}^{*}$ & 93.03 & 91.66 & 94.00 & 93.68 & 93.42 \\
\hline Red/Green value, $\mathrm{a}^{*}$ & 0.09 & 0.24 & -0.14 & 0.00 & -0.03 \\
\hline Blue/Yellow value $\mathrm{b}^{*}$ & 0.90 & 0.63 & 1.10 & 1.87 & 0.68 \\
\hline Chroma, $\mathrm{c}^{*}$ & 0.91 & 0.68 & 1.11 & 1.87 & 0.69 \\
\hline Hue angle, $\mathrm{h}^{*}$ & 84.48 & 69.49 & 97.20 & 89.86 & 92.63 \\
\hline
\end{tabular}

Color change after repeated washing cycles has been evaluated by the indicator "color difference" (table 6). The color difference $(\Delta \mathrm{E})$ is the color threshold of the human eye, with:

$\begin{array}{lll}\Delta \mathrm{E} & 0,0-1,0 & \text { «invisible» } \\ \Delta \mathrm{E} & 1,0-2,0 & \text { «barely visible» } \\ \Delta \mathrm{E} & 2,0-4,0 & \text { «visible» } \\ \Delta \mathrm{E} & 4,0-10,0 & \text { «Well visible» } \\ \Delta \mathrm{E} & >10,0 & \text { «Big difference» }\end{array}$

It is clear from plots in fig. 10 that all studied fabrics except \#2 have similar dependencies of their lightness changes during repeating washing. The values $L^{*}$ decreased. It should be noted that the lightness of fabric $\# 2$ is stable within washing $\left(L^{*}=91-92\right)$.

All studied fabrics except \#4 have similar chroma values and dependencies of their changes during repeating washing (fig.11): the fabrics' chroma increases after 10 cycles. It could be noted that the chroma value of fabric \#4 is two times higher and it increases after 5 cycles already.

Table 6: Color difference $(\Delta \mathrm{E})$ of terry fabrics after washing cycles

\begin{tabular}{|c|c|c|c|c|c|}
\hline \multirow{2}{*}{ Number of cycles } & \multicolumn{5}{|c|}{ Fabric \# } \\
\cline { 2 - 6 } & 1 & 2 & 3 & 4 & 5 \\
\hline 1 & 0.82 & 0.58 & 1.53 & 1.42 & 1.51 \\
\hline 5 & 2.03 & 0.65 & 2.52 & 3.07 & 2.84 \\
\hline 10 & 2.16 & 0.95 & 2.59 & 3.77 & 3.78 \\
\hline
\end{tabular}

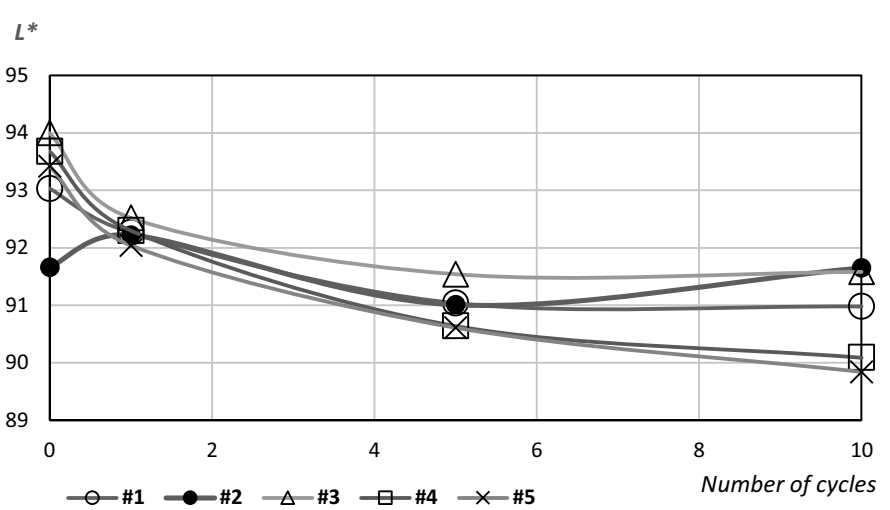

Figure 10: Changes in lightness $\left(L^{*}\right)$ after washing 


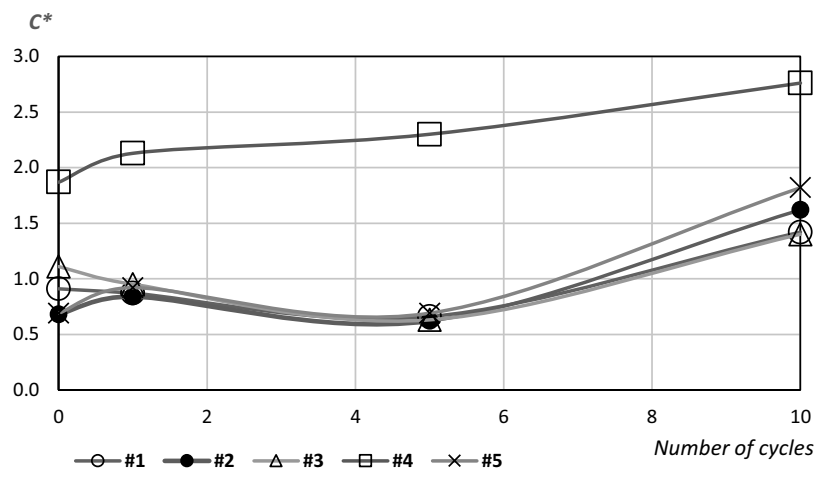

Figure 11: Changes in chroma $\left(c^{*}\right)$ after washing

\section{CONCLUSION}

Analysis of the research results indicates that only terry fabric \#2 in all indicators meets the requirements of DSTU 11027-2014. The obtained results show that fabric \#2 with $500 \mathrm{~g}$ per sq.m density and with a twisted loop $3.5 \mathrm{~mm}$ high provides a high level of water-absorbing properties and durability and can be recommended for use for hotel towel manufacture. Determining the effect of 1-10 cycles of washing on the bending strength and stiffness showed that after 10 washing cycles the strength does not change almost, and the bending stiffness decreases: the fabrics become "softer". At the same time, softening and increasing the mobility of the fabric's structure leads to a significant reduction in water absorption. This in turn worsens the comfort level of terry towels, the main purpose of which is to remove moisture from the human body. The optical properties of fabric \#2 do not change significantly within repeated washing.

\section{REFERENCES}

[1] Mazur, V. S. (2015). The hospitality industry is an effective tool for the development of tourism business. Zhurnal jevropejs'koi' ekonomiky - Journal of the European Economy, 14 (3), 273-286 [in Ukrainian].

[2] Davydova, O. A. (2017). Current state and prospects of hotel industry development in Ukraine. Visnyk Hmel'nyc'kogo nacional'nogo universytetu Bulletin of the Khmelnytsky National University, 2 (2), 257-260 [in Ukrainian].

[3] The official website of the World Tourism Organization. URL: http://www2.unwto.org/ (Last accessed: 14.05.2021).

[4] Gilmore, A. (2017). Quality and Quantity in Tourism. Journal of Hotel \& Business Management, 6(1),164.

[5] Zaharov, G. (2015). State regulation of the quality of hotel services through their certification. Derzhava ta regiony -State and regions, 1, 10-15 [in Ukrainian].

[6] DSTU 4269:2003. Tourist services. Classification of hotels. Kyiv. 2003.
[7] Buzov B. A., Alymenkova N. D. (2008). Material science in the production of light industry products (clothing manufacture). Moskva. 448 p. [in Russian].

[8] Faruque M.A.A., Kader S., Patwary S.U., Mishuk A.I., Azim A., Khatun M.S. (2015). Terry towel in Bangladesh. European Scientific Journal, 11 (3), 260-271.

[9] DSTU GOST 11027-2014. Fabrics and artificial products, cotton, terry and waffle. General specifications. Kyiv. 2014.

[10] DSTU EN 14697:2018 (EN 14697:2005, IDT). Textiles-Terry towels and terry towel fabrics. Specification and methods of test, Kyiv. 2018.

[11] Singh J.P, Behera B.K. (2015) Performance of terry towel. Indian Journal of Fibre \& Textile Research, 40, 112-121.

[12] Durur G., Oner E. (2013). The comfort properties of the terry towels made of cotton and polypropylene yarns. Journal of Engineered Fibers and fabrics. 8 (2).

[13] Legerska J. (2018) Evaluation of surface water absorbency of terry fabrics. Vlakna a Textil. 2, 59-63.

[14] Krishna Kumar V., Gokarneshan N. (2019). Functional Properties of Terry Towels. Current Trends in Fashion Technology \&Textile Engineering. 5 (1), 1-4. [in English].

[15] Gangakhedkar N.S. Colour measurement methods for textiles (2010). In Colour measurement, Woodhead Publishing Limited, Cambidge, 221-252.

Primljeno/Received on: 28.10.2021.

Revidirano/ Revised on: 28.11.2021.

Prihvaćeno/Accepted on: 30.11.2021.

(c) 2021 Authors. Published by Union of Textile Engineers and Technicians of Serbia. This article is an open access article distributed under the terms and conditions of the Creative Commons Attribution 4.0 International license (CC BY) (https://creativecommons. org/licenses/by/4.0/) 